\title{
Kira Eghbal-Azar:
}

\section{Gurrumul at the Theaterhaus Stuttgart 2009}

$\mathrm{T}$

he musician and songwriter Geoffrey Gurrumul Yunupingu was born on Elcho Island close to Arnhem Land in 1970. He is a member of the Gumatj clan, who belong to the Yolngu. Last year he was on his first official European tour. Like his debut album "Gurrumul" which was released in February 2008 the tour was a great success. His album received the attention of the international music industry and entered the charts in Australia and Europe. It also won several awards. That is why Skinnyfish Music has just released a video called "Gurrumul - Live and Behind the Scenes" which Qantas screened as part of its in-flight program on international flights between $1^{\text {st }}$ Dec 2009 and $30^{\text {th }}$ May 2010.

Gurrumul formerly performed within the famous band Yothu Yindi as a percussionist until 1992. Yothu Yindi was formed by Gurrumul's uncle Mandawuy Yunupingu. Currently Gurrumul is a member of the Saltwater Band. But it is possible that Gurrumul will become even more famous and successful than both of these Aboriginal bands.

He performed with his non-indigenous band at the Theaterhaus Stuttgart on the $28^{\text {th }}$ of October. The instrumentation consists of two guitars, one contrabass and two violins. Thus, Gurrumul doesn't use any traditional instrumentation at all. He creates a new personal style by combining traditional stories of the Gumatj clan and personal stories of himself and his family with contemporary instrumentation and song styles. Thereby he sings almost all texts in his mother tongue Yolngu matha. Hence his music is world music that connects different cultures. He makes that statement clear with his band, the instrumentation, the vocalization, himself and the opening band Wordfly, a non-indigenous Australian band from Darwin. 
Worldfly starts the concert in a lovely manner. They play inoffensive music and sing thoughtful texts. You can imagine yourself being in a pub in Darwin listening to them and just having a nice evening with friends. But when the concert started with Worldfly I was not prepared for that unbelieveable sound and feelings Gurrumul and his band are able to create. You can feel Arnhemland and its surrounding islands. You can get itchy feet for the Top End and cry together with Gurrumul about that overwhelming beautiful landscape with its endless expanse that you never get to see in Europe. As Gurrumul mother says about her blind son: "He cannot see, but he can feel."

Gurrumul tells indigenous stories to pass them down to his people and to us listeners like Aborigines are used to pass down their stories and knowledge orally. In his concert this transmission is framed by videos. As an intro to the concert you can see his uncle and his parents at their homeland talking about Gurrumul and his music. When Gurrumul sings his songs you can read the texts in English at the back of the room. You also get additional information in English about the meaning of the songs and stories. That really leads you into the matter even if you have absolutely no previous knowledge about Aboriginal cultures. The texts give the listeners a deeper understanding and hence a deeper sympathy for Gurrumul and his people. The concert ends with a video about Gurrumul's career. So the circle is closed. This arrangement really succeeds.

The most famous song Wiyathul is about the orange footed scrub fowl which has a close connection to the Gumatj. The fowls call narrates about the ancestors and their (lost) land. But Gurrumul never deals with politics like Yothu Yindi. His aim is cross cultural sensitivity. His message could be interpreted like: Be strong and stay upright no matter in which society you live.

Reviewers have called Gurrumul's voice striking and "the voice of an angel." But between his songs he never speaks. This is not only because he hardly speaks English, he is also very shy. In his clan his parents spoke for him and he was responsible for the music. During the concert the contra bassist player speaks for Gurrumul. He tells 
us about Gurrumul's worldwide success that started in Stuttgart. He tells us about the meaning of Gurrumuls music and that Gurrumul plays the guitar the other way around, in case you aren't aware of it. Then the band plays one song like Gurrumul. Thereby the band shows their empathy for Gurrumul and passes it to the audience by showing how hard it is to hold and play instruments the other way around and that Gurrumul really has great talent. He even taught himself playing didgeridoo, keyboard, percussion and guitar. Gurrumul's concerts offer a touching experience that you'll never forget. 